\title{
PENGARUH DEWAN KOMISARIS DAN KOMITE AUDIT PADA KUALITAS LAPORAN KEUANGAN
}

\author{
Tri Siwi Nugrahani. \\ trisiwinugrahani26@gmail.com, Dosen Prodi Akuntansi, F E- Universitas PGRI Yogyakarta
}

\begin{abstract}
This study aimed to examine the effect of board of directors and the audit committee on the quality of financial reporting. This research was conducted at the company's listing on the Stock Exchange in 2011-2014. The sampling method with purposive sampling and data collection methods with observation. This study tested with multiple regression analysis to test the hypothesis $t$ test with significance of $5 \%$.

Results of hypothesis testing showed that there BOC influence on quality of financial reports is proxied by Return On Investments (ROI) by $t$ test is 3,644 and significance 0,000. However, the Audit Committee did not effect the quality of financial statements with $t$ test is 1.168 and with 0.246 significance. These results indicate that the first hypothesis was supported, but the second hypothesis is not supported. The higher the BOC role in the company, the higher the Quality of Financial Statements, but if the role of the Audit Committee of the higher will not improve the quality of financial statements (proxied by ROI). Based on F test amounted to 7.538 with significance of 0,001 showed jointly between the Board of Commissioners and the Audit Committee are effect on Quality of Financial Statement. This suggests the hypothesis 3 is supported. If the BOC rose by 1 then the quality of the Financial Statements (ROI) will go up 0159, but if the Audit Committee to rise by 1 it will not increase ROI. Adjusted $\mathrm{R}^{2}$ value of 0.142 which indicates the ability of the Board of Commissioners and the Audit Committee may explain the ROI of $14.20 \%$, while the remaining $85.80 \%$ is explained by other variables.
\end{abstract}

Keywords : Board of Commissioners, the Audit Committee and the Quality of Financial Statements

Penelitian ini bertujuan untuk menguji pengaruh dewan komisaris dan komite audit terhadap kualitas laporan keuangan. Penelitian ini dilakukan pada perusahaan yang listing di BEI tahun 2011-2014. Metode pengambilan sampel dengan purposive sampling dan metode pengambilan data dengan observasi. Penelitian ini diuji dengan alat analisis regresi berganda dengan uji hipotesis uji t dengan signifikansi $5 \%$.

Hasil pengujian hipotesis menunjukkan terdapat pengaruh Dewan Komisaris pada Kualitas Laporan keuangan yang diproksikan dengan Return On Investement (ROI) dengan uji t sebesar3,644 dengan signifikansi 0,000. Namun Komite Audit tidak berpengaruh terhadap Kualitas Laporan Keuangan dengan nilai t sebesar 1,168 dengan signifikansi 0,246. Hasil tersebut menunjukkan bahwa hipotesis 1 didukung, namun hipotesis 2 tidak didukung. Semakin tinggi Dewan Komisaris berperan pada perusahaan maka semakin tinggi pulaKualitas Laporan Keuangan perusahaan, namun apabila peran Komite Audit semakin tinggi maka tidak akan meningkatkan Kualitas Laporan Keuangan (yang diproksikan dengan ROI). Berdasar uji F sebesar 7,538 dengan signifikansi 0,001 menunjukkan secara bersama-sama antara Dewan Komisaris dan Komite Audit berpengaruh terhadap Kualitas Keuangan. Hal ini menunjukkan hipotesis 3 didukung. yang berarti secara bersama-sama Dewan Komisaris dan Komite Audit berpengaruh padaKualitas Laporan Keuangan. Apabila Dewan Komisaris naik sebesar 1 maka Kualitas Laporan Keuangan (ROI) akan naik 0.159, namun jika dengan Komite Audit naik sebesar 1 maka tidak akan meningkatkan ROI. Nilai Adjusted $\mathrm{R}^{2}$ sebesar 0,142 yang menunjukkan kemampuan Dewan Komisaris dan Komite Audit dapat menjelaskan ROI sebesar 14,20\%, sedangkan sisanya sebesar 85,80\% dijelaskan oleh variabel lain.

Keywords: Dewan Komisaris, Komite Audit dan Kualitas Laporan Keuangan 


\section{PENDAhuluan}

\section{A. Latar Belakang Masalah}

Kualitas laporan keuangan akan berakibat pada peningkatan kepercayaan investor terhadap kepemilikan saham, selain itu hsil laporan keuangan yang sudah diaudit juga meningkatkan mutu laporan. Tentunya perusahaan akan memilih auditor yang harus memahami bisninya supaya dalam pemeriksaan dapat berjalan dengan efisien dan efektif, disamping itu dengan pemilikan auditor yang ahli memperkecil resiko audit, sehinggalaporan keuangan perusahaan sesuai dengan standar auditing yang ditetapkan. Sebuah perusahaan yang baik tentunya menjaga tata kelola yang baik, transparan dan akuntabel, yang salah satunya juga dari keberadaan auditor yang dimiliki oleh perusahaan dan diwadahi dalam suatu komite audit.

Menurut Braiotta (2004) komite audit mempunyai peran penting pada tata kelola perusahaan. Komite audit berperan mengawasi dan memonitor aktivitas sistem pelaporan keuangan perusahaaan. Kepemilikan aset, kemampuan manajemen operasi juga dapat mempengaruhi dari kualitas laporan keuangan, sehingga diperlukan suatu dewan komisaris yang mamppu untuk mengontrol jalannya perusahaan. Susunan dewan komisaris turut berperan dengan peningkatan kepercayaan public terhadap kualitas laporan keuangan.

Menurut Bapepam No.SE/03PM/2000 yang dimaksud komite audit adalah suatu komite yang dibentuk oleh dewan komisaris dengan memberikan pendapat professional yang independen untuk meningkatkan kualitas kerja serta mengurangi penyimpangan pengelolaan perusahaan. Pada negara maju seperti Amerika dan Inggris, komite audit pada saat ini telah diakui keberadaannya meskipun hingga saat ini belum ada kesepakatan untuk mengukur tolok ukur keberhasilan atau efektivitas komite audit (Effendi, 2005). Sedangkan pendapat rice Waterhouse yang dikemukakan oleh McMullen (1996) dalam Hasnati (2014) bahwa investor, analisis dan regulator menganggap komite audit berkontribusi dalam kualitas laporan keuangan, dengan cara: 1) pengawasan atau proses pelaporan termasuk sistem pengendalian internal dan penggunaan prinsip akuntansi secara akuntansi, dan 2) mengawasi proses audit secara keseluruhan. Hasil dari komite audit mengindikasikan bahwa komite audit memiliki konsekuensi pada laporan keuangan yaitu: 1) berkurangnya pengukuran akuntansi yang tidak tepat, 2) berkurangnya pengungkapan akuntansi yang tidak tepat, dan 3) berkurangnya tindakan kecurangan manajemen dan tindakan illegal.

Hasnati (2014) mengemukakan komisaris independen dan komite audit bertugas untuk mengatur iklim yang lebih objektif dan independen demi menjaga keadilan dan meyeimbangkan antara kepentingan pemegang saham mayoritas dan saham minoritas serta kepentingan stakeholder. Komisaris independen dan komite audit sangat diperlukan oleh perusahaan publik. Komisaris independen memiliki manfaat yang besar, terutama untuk mewujudkan prinsip Good Corporate Governance (GCG), komisaris independen dapat memberi pendapat dengan tingkat yang lebih tinggi independensi dan akuntabilitas. Selain komite audit, yaitu dewan komisaris juga memgang peranan penting di perusahaan, terutama berkaitan dengan good corporate governance (tata kelola perusahaan). Dewan komisaris berfungsi sebagai monitoring yang dipengaruhi oleh jumlah atau ukuran. Jumlah anggota dewan komisaris akan mempengaruhi tingkat kesulitan dalam menjalankan perannya, diantaranya kesulitan dalam berkomunikasi dan 
mengkoordinasi kerja dari masing-masing anggota dewan itu sendiri, kesulitan dalam mengawasi dan mengendalikan tindakan dari manajemen, serta kesulitan dalam pengambilan keputusan yang berguna untuk perusahaan.

Komite audit dan dewan komisaris tentunya berperan dalam menciptakan tata kelola perusahaan. Tata kelola perusahaan yang baik memiliki karakteristik dasar diantaranya: transparansi, keadilan, akuntabilitas, dan responsibilitas. Salah satu penilaian tata kelola perusahaan yang baik dapat dilihat pada kualitas laporan keuangan yang menggambarkan kondisi perusahaan. Manajer perusahaan dalam menyajikan laporan keuangan memperhatikan tata kelola yang dituangkan secara transparan dan akuntabel, dengan mengemukakan pula kepemilikian komite audit dan dewan komisaris yang dituangkan dalam ikhtisar laporan keuangan. Hal ini yang menimbulkan minat peneliti untuk menguji pengaruh komite audit dan dewan komisaris terhadap kualitas laporan keuangan.

\section{B. Rumusan Masalah}

Berdasarkan uraian diatas maka rumusan masalah yang akan dikaji dan diteliti dalam penelitian ini sebagai berikut:

1. Apakah terdapat pengaruh komite audit terhadap kualitas audit?

2. Apakah terdapat dewan komisaris berpengaruh terhadap kualitas audit?

\section{KERANGKA TEORI DAN PENGEMBANGAN HIPOTESIS}

\section{A. Kajian Teori}

\section{Komite Audit}

a. Pengertian Komite Audit

Komite audit adalah suatu komite yang yang dibentuk oleh dewan komisaris dan bertanggung jawab kepada dewan komisaris dengan tugas dan tanggung jawab utama untuk memastikan prinsip tata kelola yang baik terutama transparansi dan pengungkapan diterapkan secara konsisten dan memadai para eksekutif (Tjager, dkk 2003 dalam Hasnati, 2014). Sedangkan Sarbanes Oxley Act mengartikan komite audit sebagai sebuah komite (atau badan yang setingkat) yang didirikan oleh dan terdiri atas Board of Directors dengan tujuan mengawasi proses pelaporan akuntansi dan keuangan dan audit atas laporan keuangan perusahaan.

Menurut Arrens \& Loebbecke (2000), komite audit yang dikemukakan oleh Effendi (2005) adalah sebagai berikut:

An audit committee is a selected number of members of company board of directors whose responsibilities include helping auditors remain independent of management. Most audit committees are made up of three to five or sometimes as many as seven directors who are not part of company management.

b. Fungsi Komite Audit

Kehadiran komite mendapat sambutan positif dari berbagai pihak termasuk pengelola pasar modal, pemerintah, masyarakat investor, profesi hukum dan profesi auditor. Namun, sayangnya meskipun komite audit telah berkembang luas dikalangan organisasi usaha di negara-negara maju, fungsi dan peranan belum pernah dirumuskan secara definitif (Hasnati, 2014). Hal tersebut difahami karena evolusi yang masih terus berlangsung dalam fungsi dan peranannya. 
Tetapi, berdasar model yang berkembang sebagai tradisi, fungsi dan peranan komite audit adalah mewakili para pemegang saham dan dewan komisaris dalam lima hal, antara lain:

1) Penunjukkan atau penominasian auditor independen

2) Review kegiatan serta hasil kegiatan auditor

3) Review atas sistem pengendalian, termasuk auditor internal

4) Review terhadap laporan-laporan manajemen, terutama laporan keuangan

5) Identifikasi hal-hal yang memerlukan investigasi khusus oleh dewan komisaris.

c. Ketentuan Pembentukan Komite Audit

Menurut Surat Edaran Direksi PT. Bursa Efek Indonesia No. SE.008/BEJ/12-2001 tertanggal 7 Desember 2001 ketentuan anggota komite audit adalah:

1) Jumlah anggota komite audit sekurang-kurangnya tiga orang

2) Anggota komite audit yang berasal dari komisarishanya atu orang. Anggota komite audit yang berasal dari komisaris gtersebut harus merupakan komisaris independen perusahaan tercatat yang sekaligus menjadi ketua komite audit.

Anggota lain dari komite audit berasal dari pihak eksternal yang independen. Pihak eksternal adalah pihak di luar perusahaan tercatat ayaitu pihak yang bukan komisaris, direksi dan karyawan. Adapun pihak yang independen adalah pihak di luar perusahaan tercatat yang tidakmemiliki hubungan usaha dan hubungan afiliasi dengan perusahaan, komisaris, direksi dan pemegang saham utama dan mampu member pendapat profesiona secara bebas sesuai dengan etika profesionalnya, tidak memihak kepada kepentingan siapapun.

d. Peran Komite Audit

Kehadiran komite mendapat sambutan positif dari berbagai pihak termasuk pengelola pasar modal, pemerintah, masyarakat investor, profesi hukum dan profesi auditor. Namun, sayangnya meskipun komite audit telah berkembang luas dikalangan organisasi usaha di negara-negara maju, fungsi dan peranan belum pernah dirumuskan secara definitif (Hasnati, 2014). Hal tersebut difahami karena evolusi yang masih terus berlangsung dalam fungsi dan peranannya. Tetapi, berdasar model yang berkembang sebagai tradisi, fungsi dan peranan komite audit adalah mewakili para pemegang saham dan dewan komisaris dalam lima hal, antara lain:

1) Penunjukkan atau penominasian auditor independen

2) Review kegiatan serta hasil kegiatan auditor

3) Review atas sistem pengendalian, termasuk auditor internal

4) Review terhadap laporan-laporan manajemen, terutama laporan keuangan

5) Identifikasi hal-hal yang memerlukan investigasi khusus oleh dewan komisaris.

e. Tanggung Jawab Komite Audit

Tanggung jawab auditor meliputi: pemilihan auditor independen, mengawasi proses audit dan memastikan kualitas laporan keuangan. Bapepam juga mengemukakan tanggung jawab komite audit antara lain: 
1) Melakukan penelaahan atas informasi keuangan yang akan dikeluarkan perusahaan, seperti laporan keuangan, proyeksi serta informasi keuangan lain.

2) Melakukan penelaahan atas ketaatan perusahaan terhadap peraturan perundang-undangan di bidang pasar modal dan peraturan lain yang berkaitan dengan kegiatan perusahaan.

3) Melakukan penelaahan atas kecukupan pemeriksaan yang dilakukan oleh akuntan publik untuk memastikan semua resiko yang pentinguntuk dipertimbangkan.

f. Syarat Anggota Komite Audit

Menurut keputusan ketua Bapepam No.Kep-41/PM/2003 tanggal 22

Desember tentang Peraturan No: XI.1.5 berisi pembentukan dan pedoman pelaksanaan kerja komite audit adalah sebagai berikut:

1) Memiliki integritas yang tinggi, kemampuan, pengetahuan dan pengalaman yang memadai sesuai dengan latar belakang pendidikan serta mampu berkomunikasi dengan baik.

2) Salah seorang dari komite audit memiliki latar belaanh pendidikan akuntansi dan keuangan

3) Memiliki pengetahuan yang cukup untuk membaca dan memahami laporan keuangan

4) Memiliki pengetahuan yag memadai tentang peraturan bidang Pasar Modal dan Peraturan Undang-undang terkait.

5) Bukan merupakan orang dalam Kantor Akuntan Publik yang memberikan jasa audt atau non audit pada emiten atau perusahaan publik yang bersangkutan dalam satu tahun terakhir sebelum diangkat oleh Komisaris seperti dalam Peraturan No. VIII No. A.2. tentang Independensi Akuntan yang memberikan jasa audit di pasar modal.

6) Bukan merupakan karyawan kunci emiten atau perusahaan publik dalam satu tahun terakhir sebelum diangkat oleh komisaris.

7) Tidak mempunyai saham baik langsung maupun tidak langsung pada emiten atau perusahaan public. Dalam hal anggota komite audit memperoleh saham akibat peristiwa hokum maka dalam jangka waktu paling lama enam bulan setelah diperoleh saham tersebut wajib mengalihkan ke pihak lain.

8) Tidak mempunyai hubungan afiliasi dengan emiten atau perusahaan publik, komisaris, direksi atau pemegang saham utama emiten atau perusahaan public

9) Tidak memiliki hubungan usaha baik langsug maupun tidak langsung yang berkaitan dengan kegiatan usaha emiten atau perusahaan publik.

g. Faktor Dominan Keberhasilan Komite Audit

Effendi (2005) mengungkapkan bahwa terdapat 3 (tiga) faktor dominan pada keberhasilan tugas komite audit antara lain :

1) Kewenangan formal dan tertulis bagi komite audit.

2) Kerjasama manajemen.

3) Kualitas (kompetensi) personil dari komite audit.

Selain faktor-faktor tersebut, satu aspek yang cukup penting menunjang keberhasilan komite audit dalam menjalankan tugasnya adalah masalah komunikasi. Oleh karena itu komite audit harus meningkatkan komunikasi dengan 
dewan komisaris, manajemen, internal auditor dan eksternal auditor. Adanya komunikasi yang lancar antara komite audit dengan berbagai pihak dapat menunjukkan kinerja komite audit lebih efektif dan dapat meringankan tugas komisaris dalam mengawasi jalannya perusahaan.

\section{Dewan Komisaris}

a. Pengertian Dewan Komisaris

Menurut UU PT No. 40 Tahun 2007 dalam Pasal 108 ayat 2, mengharuskan kelembagaan komisaris sebagai salah satu organ perseroan, bahkan perseroan yang kegiatan usahanya berkaitan dengan menghimpun dana masyarakat, perseroan yang menerbitkan surat pengakuan utang kepada masyarakat atau perseroan terbuka wajib mempunyai paling sedikit dua orang komisaris.

Sedangkan pengertian dewan komisaris menurut UU PT Pasal 1 butir 6 dan Pasal 108 ayat 1 dan 2, yaitu: organ perseroan yang bertugas melakukan pengawasan secara umum dan atau khusus sesuai dengan anggaran dasar serta memberikan nasehat kepada direksi.

Dalam rangka mengawasi dan menegakkan pelaksanaan fiduciary duties oleh direksi atau komisaris, maka UU PT menetapkan bahwa pemegang saham yang mewakilipaling sedikit sepersepuluh (1/10) bagian jumlah saham dengan hak suara yang sah dapat mengajukan gugatan terhadap direksi atau komisaris yang karena salah atau kelalaiannya menimbukan kerugian perseroan (Pasal 97 ayat 6, dan Pasal 114 ayat 6).

Menurut Efendi (2005) dewan komisaris melakukan pengawasan atas kebijakan pengurusan jalannya perusahaan pada umumnya, baik mengenai perseroan maupun usaha perseroan dan memberi nasehat kepada direksi. Kesemuanya itu dilakukan untuk kepentingan perseroan dan sesuai dengan maksud dan tujuan perseroan. Hal yang dimaksud dengan "untuk kepentingan dan sesuai dengan maksud dan tujuan perseroan" adalah bahwa pengawasan dan pemberian nasehat yang dilakukan oleh dewan komisaris tidak untuk kepentingan pihak atau golongan tertentu tetapi untuk kepentingan perseroan secara menyeluruh sesuai dengan maksud serta tujuan perseroan. Direksi menjalankan pengurusan Perseroan untuk kepentingan Perseroan dan sesuai dengan maksud dan tujuan Perseroan.

b. Kewajiban Dewan Komisaris

Menurut UU PT Pasal 116 Tahun 2007 menyatakan kewajiban dewan komisaris antara lain:

1) Membuat risalah rapat dewan komisaris dan menyimpan salinan rapat

2) Melaporkan kepada perseroan tentang kepemilikan saham dan atau keluarga atas saham perseroan dan saham di perseroan lain.

3) Memberikan laporan tentang tugas pengawasan yang telah dilakuka

4) Mengawasi direktur 
Dewan komisaris juga memiliki wewenang untuk member persetujuan atas bantuan kepada direksi dalam melakukan perbuatan hukum tertentu seperti diatur dalam Pasal 117 UU PT.

5) Pengajuan Pailit

Menurut Efendi (2005), direksi tidak berwenang mengajukan permohonan pailit atas perseroan sendiri kepada Pengadilan Niaga sebelum memperoleh persetujuan RUPS, dengan tidak mengurangi ketentuan sebagaimana diatur dalam undang-undang tentang Kepailitan dan Penundaan Kewajiban Pembayaran Utang. Dalam hal kepailitan sebagaimana dimaksud, terjadi karena kesalahan atau kelalaian Direksi dan harta pailit tidak cukup untuk membayar seluruh kewajiban Perseroan dalam kepailitan tersebut, setiap anggota Direksi secara tanggung renteng bertanggung jawab atas seluruh kewajiban yang tidak terlunasi dari harta pailit tersebut.

Tanggung jawab sebagaimana dimaksud pada ayat 2 berlaku juga bagi anggota Direksi yang salah atau lalai yang pernah menjabat sebagai anggota Direksi dalam jangka waktu 5 (lima) tahun sebelum putusan pernyataan pailit diucapkan. Anggota Direksi tidak bertanggungjawab atas kepailitan Perseroan sebagaimana dimaksud pada ayat (2) apabila dapat membuktikan:

1) kepailitan tersebut bukan karena kesalahan atau kelalaiannya;

2) telah melakukan pengurusan dengan itikad baik, kehati-hatian, dan penuh tanggung jawab untuk kepentingan Perseroan dan sesuai dengan maksud dan tujuan Perseroan;

3) tidak mempunyai benturan kepentingan baik langsung maupun tidak langsung atas tindakan pengurusan yang dilakukan; dan

4) telah mengambil tindakan untuk mencegah terjadinya kepailitan.

c. Syarat Dewan Komisaris

Adapun syarat Dewan Komisaris sebagai berikut:

1) Integritas, yaitu memiliki akhlak dan moral yang baik, komitmen untuk mematuhi peraturan perundang undangan yang berlaku, komitmen yang tinggi terhadap pengembangan operasional bank yang sehat, dan tidak termasuk dalam daftar tidak lulus sesuai dengan ketentuan yang di tetapkan oleh bank indonesia.

2) Kompetensi, yaitu :

a) Memiliki pengetahuan dibidang perbankan yang memadai dan relevan dengan jabatannya dan atau

b) Memiliki pengalaman dibidang perbankan.

Pengangkatan menjadi anggota Dewan Komisaris adalah orang perseorangan yang cakap melakukan perbuatan hukum, kecuali dalam waktu 5 (lima) tahun sebelum pengangkatannya pernah:

i. dinyatakan pailit;

ii. menjadi anggota Direksi atau anggota Dewan Komisaris yang dinyatakan bersalah menyebabkan suatu Perseroan dinyatakan pailit; atau

iii. dihukum karena melakukan tindak pidana yang merugikan keuangan negara dan/atau yang berkaitan dengan sektor keuangan. 
Ketentuan persyaratan sebagaimana dimaksud pada ayat (1) tidak mengurangi kemungkinan instansi teknis yang berwenang menetapkan persyaratan tambahan berdasarkan peraturan perundang-undangan. Pemenuhan persyaratan sebagaimana dimaksud pada ayat (1) dan ayat (2) dibuktikan dengan surat yang disimpan oleh Perseroan.

\section{Kualitas Laporan Keuangan}

Menurut Fanani (2008), pengertian kualitas pelaporan keuangan hingga saat ini masih beragam, namun pada prinsipnya pengertian kualitas pelaporan keuangan dapat dipandang dalam dua sudut pandang. Pandangan pertama menyatakan bahwa kualitas pelaporan keuangan berhubungan dengan kinerja keseluruhan perusahaan yang tergambarkan dalam laba perusahaan. Pandangan ini menyatakan laba yang berkualitas tinggi terrefleksi pada laba yang dapat berkesinambungan (sustainable) untuk suatu perioda yang lama. Pandangan kedua menyatakan kualitas pelaporan keuangan berkaitan dengan kinerja pasar modal yang diwujudkan dalam bentuk imbalan, sehingga hubungan yang semakin kuat antara laba perusahaan dengan imbalan menunjukkan informasi pelaporan keuangan yang tinggi (Ayres, 1994). Pandangan yang sama dilakukan oleh Schipper (2004) dengan menyebutnya sebagai atribut-atribut berbasis akuntansi untuk pandangan pertama, dan atribut-atribut berbasis pasar untuk pandangan kedua.

Pandangan pertama menyatakan bahwa kualitas pelaporan keuangan berkaitan erat dengan kinerja perusahaan yang diwujudkan dalam laba perusahaan yang diperoleh pada tahun berjalan. Pelaporan keuangan dikatakan tinggi (berkualitas) jika laba tahun berjalan dapat menjadi indikator yang baik untuk laba perusahaan dimasa yang akan datang (Lev dan Thiagarajan, 1993; Richardson et al. 2001; Penman dan Zhang, 2002; Beneish dan Vargus, 2002; Richardson, 2003) atau berasosiasi secara kuat dengan arus kas operasi di masa yang akan datang (Dechow dan Dichev, 2002 dan Cohen, 2003).

Implikasi dari pandangan tersebut, menunjukkan bahwa fokus pengukuran kualitas pelaporan keuangan perusahaan tersebut berkaitan dengan sifat-sifat pelaporan keuangan. Pandangan kedua menyatakan bahwa kualitas pelaporan keuangan berkaitan dengan kinerja saham perusahaan di pasar modal. Hubungan yang semakin kuat antara laba dengan imbalan pasar menunjukkan informasi pelaporan keuangan tersebut semakin tinggi (Lev dan Thiagarajan, 1993; Chan et al. 2004). Dengan demikian kualitas pelaporan keuangan merupakan konstruk yang dapat dianalisis dalam dua pandangan yaitu kualitas pelaporan keuangan yang berkaitan dengan kas dan laba itu sendiri, dan atau kualitas pelaporan keuangan yang berkaitan dengan imbalan saham (Fanani, 2008).

Perkembangan terbaru membuktikan bahwa manajemen tidak cukup hanya memastikan bahwa proses pengelolaan manajemen berjalan dengan efisien. Diperlukan instrumen baru, Good Corporate Governance (GCG) untuk memastikan bahwa manajemen berjalan dengan baik. Ada dua hal yang ditekankan dalam konsep ini, pertama, pentingnya hak pemegang saham untuk memperoleh informasi dengan benar dan tepat pada waktunya dan, kedua, kewajiban perusahaan untuk melakukan pengungkapan (disclosure) secara akurat, 
tepat waktu, dan transparan terhadap semua informasi kinerja perusahaan, kepemilikan, dan stakeholder. Dari berbagai hasil pengkajian yang dilakukan oleh berbagai lembaga riset independen nasional dan internasional, menunjukkan rendahnya pemahaman terhadap arti penting dan strategisnya penerapan prinsipprinsip GCG oleh pelaku bisnis di Indonesia. Selain itu, budaya organisasi turut mempengaruhi penerapan GCG di Indonesia.

Penelitian ini menggunakan pengukuran kualitas laporan keuangan dengan besarnya laba yang diperleh atau keuntungan Return On Investment (ROI).

\section{B. Pengajuan Hipotesis}

Berdasarkan hasil-hasil penelitian yang telah dilakukan sebelumnya yang berkaitan dengan masalah yang diteliti, maka permasalahan yang diangkat dalam penelitain ini dihipotesiskan sebagai berikut :

1. HI: Terdapat pengaruh komite audit terhadap kualitas laporan keuangan

2. H2: Terdapat pengaruh dewan komisaris terhadap kualitas laporan keuangan

3. H3: Terdapat pengaruh komite audit dan dewan komisaris terhadap kualitas laporan keuangan

\section{METODA PENELITIAN}

\section{A. Sampel Penelitian}

Sampel penelitian ini adalah perusahaan yang terdaftar dalam BEI selama tahun 2012-2015. Metode penentuan sampel dengan purposive sampling dengan kriteria perusahaan listing di BEI dan memiliki Dewan Komisaris, dan Komite Audit selama tahun 2012-2015.

B. Metode Pengumpulan Data

Data diperoleh dengan melakukan observasi perusahaan manufaktur yang terdaftar di BEI selama tahun 2012-2015. Data yang digunakan adalah data sekunder yaitu Laporan keuangan perusahaan manufaktur yang listing di BEI selama tahun 2012 sampai 2015.

C. Variabel Penelitian

Variabel penelitian ini terdiri dari tiga variabel yaitu komite audit dan dewan komisaris sebagai variabel independen, sedangkan kualitas laporan keuangan sebagai variable terikat.

Pengukuran variabel dengan menggunakan dummy dan diberi skor 1 untuk perusahaan yang menggunakan dewan komisaris dan komite audit sedangkan skor 0 untuk perusahaan yang tidak menggunakan/memiliki dewan komisaris dan komite audit. Sedangkan kualitas laporan keuangan diukur dengan kemampuan perusahaan mencapai laba yang diukur dengan ROI sebagai ukuran kinerja perusahaan. Pengukuran variabel kualitas laporan keuangan dengan menggunakan skala rasio.

D. Disain Penelitian

Model penelitian ini dapat dilistrasikan sebagai berikut

\begin{tabular}{|c|}
\hline Komite Audit $\left(\mathrm{X}_{1}\right)$ \\
Dewan Komisaris $\left(\mathrm{X}_{2}\right)$
\end{tabular}$\longrightarrow \begin{gathered}\text { Kualitas Laporan Keuangan } \\
\left(\mathrm{X}_{3}\right)\end{gathered}$


E. Teknik Analisa Data

Teknik analisa data penelitian ini menggunakan bantuan sostware SPSS versi 16 dengan menggunakan alat Analisa Regresi Berganda, dengan formula sebagai berikut:

$$
\begin{array}{ll}
\mathrm{Y}=\mathrm{a}+\mathrm{b} 1 \mathrm{X} 1+\mathrm{b} 2+\mathrm{X} 2+\mathrm{e}, \text { dimana: } \\
\mathrm{Y}= & \text { Kualitas Laporan Keuangan } \\
\mathrm{X} 1= & \text { Dewan Komisaris } \\
\mathrm{X} 2= & \text { Komite Audit } \\
\mathrm{a}= & \text { Konstanta } \\
\mathrm{b} 1= & \text { koefisien regresi dewan komisaris } \\
\mathrm{b} 2= & \text { koefisien regresi komite audit } \\
\mathrm{e}= & \text { error }
\end{array}
$$

F. Uji Hipotesis

Uji hipotesa dengan menggunakan tingkat signifikansi sebesar 5\% $(\alpha<$ $0,05 \%)$.

\section{HASIL PENELITIAN DAN PEMBAHASAN}

\section{A. Deskripsi Data}

Studi ini menggunakan sampel penelitian perusahaan yang terdaftar di BEI dalam sektor makanan, sektor rokok, sektor farmasi, sektor kosmetik dan barang keperluan rumah tangga, serta sektor peralatan rumah tangga . sedangkan data perusahaan yang digunakan yaitu laporan keuangan perusahaan selama empat tahun, yaitu tahun 2011-2014. Total sampel penelitian terdiri 27 perusahaan dengan laporan keuangan tahun 2011-2014.

\section{1) Sampel Penelitian} berikut:

Berikut ini data perusahaan yang dijadikan sampel penelitian sebagai

Tabel 1. Sampel Penelitian

\begin{tabular}{|l|l|}
\hline Kriteria Sampel & $\begin{array}{l}\text { Jumlah } \\
\text { Perusahaan }\end{array}$ \\
\hline Total sampel perusahaan & 28 \\
\hline $\begin{array}{l}\text { Tidak tersedia laporan tahunan lengkap } \\
\text { dari tahun 2011-2014 }\end{array}$ & $(1)$ \\
\hline $\begin{array}{l}\text { Tersedia laporan tahunan lengkap dari } \\
\text { tahun 2011-2014 }\end{array}$ & 27 \\
\hline Sampel penelitian & 27 \\
\hline
\end{tabular}

Sumber : Data sekunder diolah, 2014

Berdasar tabel 1 menunjukkan sampel perusahaan ada 27 . dari rencana sampel perusahaan ada 28 perusahaan karena ada 1 perusahaan yang tidak lengkap yaitu PT AISA maka sampel perusahaan menjadi 27 perusahaan. 


\section{2) Daftar Perusahaan}

Berikut nama 27 perusahaan yang dijadikan sampel pengamatan penelitian, dan masing-masing perusahaan menyajikan laporan keuangan selama empat tahun mulai tahun 2011-2014. Perusahaan tersebut meliputi beberapa sektor industri.

Tabel 2. Daftar Perusahaan

\begin{tabular}{|c|c|c|c|}
\hline No & Kode & Nama Perusahaan & Tahun \\
\hline 1 & ADES & Akasha Wira Internasional & $2011-2014$ \\
\hline 2 & ALTO & Tri Banyan Tirta & $2011-2014$ \\
\hline 3 & CEKA & Wilmar cahaya Indonesia & $2011-2014$ \\
\hline 4 & DLTA & Delta Djakarta & $2011-2014$ \\
\hline 5 & ICBP & Indofood CBP Sukses Makmur & $2011-2014$ \\
\hline 6 & INDF & Indofood Sukses Makmur & $2011-2014$ \\
\hline 7 & MLBI & Multi Bintang Indonesia & $2011-2014$ \\
\hline 8 & MYOR & Mayora Indah & $2011-2014$ \\
\hline 9 & ROTI & Nippon Indosari Corporindo & $2011-2014$ \\
\hline 10 & SKLT & Sekar Laut & $2011-2014$ \\
\hline 11 & STTP & Siantar Top & $2011-2014$ \\
\hline 12 & GGRM & Gudang Garam & $2011-2014$ \\
\hline 13 & HMSP & Hanjaya Mandala Sampoerna & $2011-2014$ \\
\hline 14 & RMBA & Bentoel Internasional Investama & $2011-2014$ \\
\hline 15 & DVLA & Darya Varia Laboratoia & $2011-2014$ \\
\hline 16 & INAF & Indofarma & $2011-2014$ \\
\hline 17 & KAEF & Kimia Farma & $2011-2014$ \\
\hline 18 & KLBF & Kalbe Farma & $2011-2014$ \\
\hline 19 & MERK & Merck & $2011-2014$ \\
\hline 20 & PYFA & Pyridam Farma & $2011-2014$ \\
\hline 21 & TSPC & Tempo Scan Pasific & $2011-2014$ \\
\hline 22 & MBTO & Martina Berto & $2011-2014$ \\
\hline 23 & TCID & Mandom Indonesia & $2011-2014$ \\
\hline 24 & UNVR & Unilever Indonesia & $2011-2014$ \\
\hline 25 & KDSI & Kedawung Setia Industrial & $2011-2014$ \\
\hline 26 & $\mathrm{KICI}$ & Kedaung Indah Can & $2011-2014$ \\
\hline 27 & LMPI & Langgeng Makmur Industry & $2011-2014$ \\
\hline
\end{tabular}

\section{3) Statistik Deskriptif}

Berikut tabel 4 menunjukkan statistik deskriptif sebagai analisis awal penelitian. Tabel 4 menunjukkan nilai rata-rata (kesalahan standar tiap-tiap variabel ROI, Komite Audit dan Dewan Komisaris adalah: $0,10 \quad(0,128) ; 0,96$ $(0,249)$; dan $1,08(0,265)$, sedangkan rata-rata (kesalahan standar) harga saham, total hutang, total ekuitas, dan total assets yaitu: 14596,78 (49644,07); 
$3391901,39 \quad(8182489,25) ; \quad 3479061,62 \quad(7792396,07) ; \quad$ dan $\quad 6493749,57$ $(1,42653287)$.

Tabel 4.Statistik deskriptif

\begin{tabular}{|l|l|l|l|l|l|}
\hline & $\mathrm{N}$ & Minimum & Maximum & Mean & Std. Deviation \\
\hline ROI & 144 & 0 & 1 & 0,10 & 0,128 \\
Komite Audit & 80 & 0 & 2 & 0,96 & 0,249 \\
Dewan Komisaris & 93 & 1 & 2 & 1,08 & 0,265 \\
Harga Saham & 192 & 0 & 390000 & 14596,78 & 49644,07 \\
Total Hutang & 142 & 0 & 57766682 & 3391901,39 & 8182489,25 \\
Total Ekuitas & 144 & -1396853 & 41228376 & 3479061,62 & 7792396,08 \\
Total Assets & 144 & 68876 & 85938885 & 6493749,57 & 1,42653287 \\
Valid N (listwise) & 80 & & & & \\
\hline
\end{tabular}

4) Korelasi

Korelasi antar variabel ROI, Dewan Komisaris, dan Komite Audit dapat disajikan dalam tabel 5.

Tabel 5. Korelasi

\begin{tabular}{|ll|l|l|l|}
\hline & ROI & $\begin{array}{l}\text { Dewan } \\
\text { komisaris }\end{array}$ & $\begin{array}{l}\text { Komite } \\
\text { Audit }\end{array}$ \\
\hline pearson & ROI & 1.000 & 0.386 & 0.140 \\
correlation & Dewan Komisaris & 0.386 & 1.000 & 0.047 \\
& Komite Audit & 0.140 & 0.047 & 1.000 \\
\hline sig. (1-tailed) & ROI & - & 0.000 & 0.108 \\
& Dewan Komisaris & 0.000 &. & 0.340 \\
& Komite Audit & 0.108 & 0.340 &. \\
\hline $\mathrm{N}$ & ROI & 80 & 80 & 80 \\
& Dewan Komisaris & 80 & 80 & 80 \\
& Komite Audit & 80 & 80 & 80 \\
\hline
\end{tabular}

Tabel 5 menunjukkan variabel ROI dengan Dewan Komisaris berkorelasi sebesar 0,318 dengan signifansi 0,000 dan korelasi antara ROI dengan Komite Audit sebesar 0,140 dengan signifikansi 0,0108.

\section{B. Pengujian Hipotesis}

Pengujian hipotesis menggunakan uji t dalam regresi berganda dengan tingkat signifikansi 5\%. Adapun tabel 6 menunjukkan hasil pengujian hipotesis sebagai berikut :

Tabel 6. Uji Hipotesis

\begin{tabular}{|l|l|l|l|l|}
\hline Variabel & Koefisien b & t & Sig & Ket \\
\hline Konstanta & $-0,111$ & $-1,659$ & 0,101 & \\
\hline Dewan Komisaris & 0,159 & 3,644 & 0,000 & Didukung \\
\hline Komite Audit & 0,058 & 1,168 & 0,264 & Tidak Didukung \\
\hline $\mathrm{F}=7,538$ & $\mathrm{R}^{2}=0,164$ \\
\hline Prob $=0,001$ & $\operatorname{Adj~}^{2}=0,142$ \\
\hline
\end{tabular}


Pada tabel 6 menunjukkan nilai t dewan komisaris sebesar 3,644 dan siginifikan 0,00 yang menunjukkan dewan komisaris berpengaruh pada kualitas laporan keuangan. Dalam hal ini uji hipoptesis 1 didukung karena $p \quad 0,05$. Sedangkan nilai $\mathrm{t}$ pada variabel komite audit menunjukkan 1,168 dengan signifikansi 0,245. Ini berarti komite audit tidak berpengaruh pada kualitas audit. Hasil tersebut menunjukkan bahwa hipotesis ke 2 tidak didukung karena p. 0,05.

Tabel 6 juga menunjukkan nilai $\mathrm{F}$ sebesar 7,538 dengan signifikansi 0,001 hal ini mengartikan dewan komisaris dan komite audit secara bersamasama berpengaruh pada kualitas laporan keuangan. Sesuai dengan pengajuan hipotesis 3 bahwa dewan komisaris dan komite audit berpengaruh pada kualitas laporan keuangan, maka dengan melihat hasil nilai $\mathrm{F}$ dan siginifikan 0,001 serta berada dalam rentang $\mathrm{p}$ value 0,05 berarti pengajuan hipotesis 3 didukung.

Pada tabel 6 menunjukkan nilai Adjusted $\mathrm{R}^{2}$ sebesar 0,164 berarti kemampuan dewan komisaris dan komite audit dapat menjelaskan kualitas laporan keuangan yang diproksikan dengan ROI sebesar 14,20\%, sedangkan sisanya sebesar $85,50 \%$ dijelaskan oleh variabel lain.

\section{Pembahasan Hasil Penelitian}

Hasil pengujian hipotesis 1 yaitu pengaruh Dewan Komisaris pada kualitas Laporan Keuangan menunjukkan 3,644 dengan signifikansi 0,000 yang berarti didukung. Hasil penelitian ini menunjukkan dewan Komisaris berpengaruh pada Kualitas Laporan Keuangan (dalam hal ini diproksikan dengan ROI). Semakin banyak/tinggi Dewan Komisaris yang dilakukan oleh perusahaan semakin tinggi pula ROI perusahaan.

Hipotesis 2 yang berbunyi Komite Audit berpengaruh pada ROI. Berdasar hasil uji hipotesis menunjukkan nilai t sebesar 1,168 dengan signifikansi 0,246 yang berarti pengajuan hipotesis 2 tidak didukung. Hasil ini penelitian ini menunjukkan bahwa Komite Audit tidak berpengaruh secara statistik terhadap nilai ROI, karena nilai signifikansi $>0,05$. Komite audit berpengaruh pada ROI pada level kepercayaan $75 \%$.

Secara bersama-sama antara Komite Audit dan Dewan Komisaris berpengaruh terhadap ROI dengan memperhatikan nilai F sebesar 7,538 dengan signifikansi 0,001. Hal ini menunjukkan bahwa pengajuan hipotesis 3 didukung yang berarti Secara bersama-sama Dewan Komisaris dan Komite Audit berpengaruh pada ROI. Apabila Dewan Komisaris naik sebesar 1 maka ROI akan naik 0.159, demikian pula jika Komite Audit naik sebesar 1 maka akan meningkatkan ROI sebesar 0,058.

\section{KESIMPULAN DAN SARAN}

\section{A. Kesimpulan}

Penelitian ini bertujuan untuk menguji pengaruh Dewan Komisaris dan Komite Audit terhadap Kualitas LaporanKeuangan yang diproksikan dengan ROI (return On Investment). Berdasarkan analisis data dan pembahasan diperoleh kesimpulan sebagai berikut: 
Hipotesis 1 yaitu pengaruh Dewan Komisaris pada kualitas Laporan Keuangan menunjukkan 3,644 dengan signifikansi 0,000 yang berarti didukung. Hasil penelitian ini menunjukkan Dewan Komisaris berpengaruh pada Kualitas Laporan Keuangan (dalam hal ini diproksikan dengan ROI). Semakin banyak/tinggi Dewan Komisaris yang dilakukan oleh perusahaan semakin tinggi pula ROI perusahaan.

Hipotesis 2 yaitu Komite Audit berpengaruh pada ROI. Berdasar hasil uji hipotesis menunjukkan nilai t sebesar 1,168 dengan signifikansi 0,246 yang berarti pengajuan hipotesis 2 tidak didukung. Hasil ini penelitian ini menunjukkan bahwa Komite Audit tidak berpengaruh secara statistik terhadap nilai ROI, karena nilai signifikansi $>0,05$. Komite audit berpengaruh pada ROI pada level kepercayaan $75 \%$.

Secara bersama-sama antara Komite Audit dan Dewan Komisaris berpengaruh terhadap ROI dengan memperhatikan nilai $\mathrm{F}$ sebesar 7,538 dengan signifikansi 0,001. Hal ini menunjukkan bahwa pengajuan hipotesis 3 didukung yang berarti Secara bersama-sama Dewan Komisaris dan Komite Audit berpengaruh pada ROI. Apabila Dewan Komisaris naik sebesar 1 maka ROI akan naik 0.159, demikian pula jika Komite Audit naik sebesar 1 maka akan meningkatkan ROI sebesar 0,058.

B. Saran

Berdasarkan hasil penelitian yang telah dilakukan, sebaiknya penelitian mendatang mengelompokkan pembahasan sampel perusahaan berdasar jenis industri, sehingga mendapatkan hasil yang lebih baik. Selain itu perlu diperhatikan keterbatasan penelitian, diantaraya periode penelitian hanya empat tahun kemungkinan apabila ditambah periode pengamatan hasil akan lebih valid, dan penelitian ini tidak dapat digeneralisasi kemungkinan hasil akan berbeda jika sampel perusahaan dibedakan berdasar jenis usaha.

\section{DAFTAR PUSTAKA}

Braiotta, Louis, Jr (2004), The Audit Committee Handbook IIA (Institute of Internal Auditors) Series, Wiley

Bapepam (2000), Pembentukan Komite Audit, Surat Edaran Bapepam No.SE/03PM/2000

Effendi, M. A. (2005): "Peranan Komite Audit Dalam Meningkatkan Kinerja Perusahaan, Jurnal Akuntansi Pemerintah," Vol. 1 No. 1, Mei 2005, Hlm. 51 - 57, ISSN : 0216-8642

Fanani. M (2008), Kualitas Pelaporan Keuangan: Faktor-faktor penentu dan Konsekuensinya, The $2^{\text {nd }}$ Accounting Conference $1^{\text {st }}$ Doctoral Collocium, and Accounting Workshop Depok, 4-5 Nopember.

Hasnati (2014), "Komisaris Indepennden dan Komite Audit-Organisasi Perusahaan yang Berperan Untuk Mewujudkan Good Corporate Governance di Indonesia”, Absolut Media.

Surat Edaran Direksi PT. Bursa Efek Indonesia (2001) No. SE.008/BEJ/12-2001. Ketentuan Anggota Komite Audit, tanggal 7 Desember 2001.

Surat Keputusan Bapepam. (2003), No.Kep-41/PM/2003: Peraturan No: XI.1.5 tentang "Pembentukan dan Pedoman Pelaksanaan Kerja Komite Audit:

Undang-Undang Negara Republik Indonesia No. 40 Tahun 2007tentang Perseroan Terbatas 